\title{
MORPHOMETRIC ANALYSIS OF FRUITS AND SEEDS OF Annona crassiflora Mart. (ANNONACEAE) FROM CENTRAL BRAZIL
}

\author{
Alexandre Cesar Palermo ${ }^{2 *}$ and Anderson Marcos de $\mathrm{Souza}^{3}{ }^{\circ}$
}

\begin{abstract}
${ }^{1}$ Received on 27.02.2018 accepted for publication on 09.08.2019.
${ }^{2}$ Universidade de Brasília, Programa de Pós-Graduação em Ciências Florestais, Brasilia, DF - Brasil. E-mail: <alexandre.ecofogo@gmail.com>.

${ }^{3}$ Universidade de Brasília, Departamento de Engenharia Florestal, Brasília, DF - Brasil . E-mail: <andermsouza@yahoo.com.br>.

*Corresponding author.
\end{abstract}

\begin{abstract}
With the existing reduction of the vegetation cover of the Cerrado, several tree species have their areas of occurrence diminished, and as a consequence, they lose part of their genetic diversity. To counter this scenario it is necessary to know the genetic diversity in order to base projects and practical conservation measures. Thus, the objective of this work was to investigate the genetic variability of Annona crassiflora by means of morphometric data of fruits and seeds in four populations in central Brazil. In total, 152 fruits were obtained from 73 matrices, of which the height, diameter, fruit mass, mass of 100 seeds and number of seeds per fruit were measured. The fruits were stripped and the seed removed to measure their height, width and thickness. The hierarchical cluster study showed the grouping of 11 small groups and two large groups, and in these two large groups there are representatives of the four populations sampled. This shows that there is no specific division of populations, indicating high genetic variability. The fruits of the Buritis population were, as a rule, significantly larger than those of other populations, which may indicate genetic distancing or different environmental conditions of pollination and dispersion. This pattern was not observed in the seed size analysis, although there was a statistical difference between the populations. In general, the largest dimensions were found in the populations of Planaltina and Buritis. Therefore, the analyzes indicate high genetic diversity and fruits/seeds with larger dimensions in the best-preserved state.
\end{abstract}

Keywords: Araticum; Cerrado; Morphometry

\section{ANÁLISE MORFOMÉTRICA DE FRUTOS E SEMENTES DE ANNONA CRASSIFLORA MART. (ANNONACEAE) DO BRASIL CENTRAL}

RESUMO - Com a existente redução da cobertura vegetal do Cerrado, diversas espécies arbóreas têm suas áreas de ocorrência diminuídas e como consequência perdem parte de sua diversidade genética. Para contrapor este cenário faz-se necessário conhecer a diversidade genética afim de embasar projetos e medidas práticas de conservação. Assim, este trabalho teve como objetivo investigar a variabilidade genética populacional de Annona crassiflora por meio de dados morfométricos de frutos e sementes em quatro populações no Brasil central. No total foram obtidos 152 frutos de 73 matrizes dos quais foram medidos a altura, diâmetro, massa do fruto, massa de 100 sementes e número de sementes por fruto. Os frutos foram despolpados e as semente retiradas para se medir a altura, largura e espessura. O estudo de cluster hierárquico mostrou o agrupamento de 11 pequenos grupos e dois grandes grupos, sendo que nestes dois grandes grupos há representantes das quatro populações amostradas. Isso mostra que não há uma divisão específica das populações, indicando alta variabilidade genética. Os frutos da população de Buritis foram, via de regra, significativamente maiores que das outras populações o que pode evidenciar distanciamento genético ou diferentes condições ambientais de polinização. Este padrão não foi observado nas analise das dimensões das sementes, embora tenha havido diferença estatística entre as populações. De forma geral as maiores dimensões foram encontradas nas populações de Planaltina e Buritis. Diante disso as análises indicam alta diversidade genética e frutos/sementes com dimensões maiores nos locais com melhor estado de conservação.

Palavras-Chave: Araticum; Cerrado; Morfometria.

\section{Silf $(c))$ EY}

Revista Árvore 2019;43(3):e430304 http://dx.doi.org/10.1590/1806-90882019000300004 


\section{INTRODUCTION}

In the past decade the Cerrado had around $40 \%$ of the vegetation altered by human activity, as shown in the study by Sano, et al. (2007) and currently $46 \%$ of its native coverage has already been lost (Strassburg, et al., 2017). This can be explained by the fact that the Cerrado has the smallest percentage of legally protected area, only $5.2 \%$, in the form of protected areas until the middle of the last decade (Jepson, 2005), and about 7.5\% today (Soares-Filho, et al., 2014). As a result, many species are threatened by disorderly anthropic occupation and predatory extractivism. This leads to irreparable losses in the area of health, welfare and economy of society, as native species of great potential for economic use such as fruit, medicinal, timber or ornamental are replaced by agricultural crops. This replacement happens without due care to good practices for the conservation of natural resources.

In addition to the creation of larger protected areas, the restoration of degraded areas and the restoration of the legal reserve of rural properties with native species seedlings help in the conservation of species with economic potential (Hopkin, 2004). Studies on the genetic variability of these species generate information to support different management practices beyond the establishment of germplasm banks and early stages of selection and genetic improvement (Faleiro, 2007).

Cerrado fruit trees play an important role in the conservation of native environments, but can also be commercially exploited, presenting agronomic potential. The main challenge of these species involves production and commercialization, where specific efforts improve knowledge and enable the advancement of this new market (Vieira, et al., 2010).

Because they are native species, their nutritional demands are compatible with the local soil and require little or no input for implantation or permanence. In addition to commercial use, these species can be employed in projects for the recovery of degraded areas, flora enrichment and restoration of environmental protection areas. The fruits of these species are traded in fairs in central Brazil region and highway margins with great consumer acceptance and competitive prices (Vieira, et al., 2010).
Based on its economic, nutritional, social and environmental potential, with a view to fostering its use by smallholder farmers and rural communities is the araticum (Annona crassiflora Mart.), Also popularly known as bruto, cabeça-de-negro, cascudo, marolo and pinha-do-cerrado.

Given the native characteristics and economic and social importance of $A$. crassiflora, there is a need for seed production with adequate genetic quality, quantity production and low cost, for implementation of native species seed orchards for environmental restoration or even economical (Higa and DuqueSilva, 2006). These orchards, in addition to serving as seed suppliers for restoration of areas, can meet the precept of genetic conservation ex situ, as well as providing information and genetic material for the feasibility of genetic improvement programs.

However, when dealing with genetic material for forest restoration, the use of seeds with wide genetic variability is necessary, maintaining the gene pool of the species in the region, based on the use of seeds from the same collection and use zone. This fact is important because the genetic variation of species is associated with their geographical distribution. Defining the boundaries of seed collection and use zones should be based on experimental data identifying genetic variation, or by analyzing environmental factors that are likely to have the greatest influence on the creative forces of such genetic variation (Bower and Aitkens, 2008).

In response to the great economic, social and environmental importance of araticum, this study aimed to investigate the population genetic diversity of Annona crassiflora through a detailed study of fruit and seed morphometric data in four populations in central Brazil.

\section{MATERIAL AND METHODS}

\subsection{Matrix selection, seed collection and beneficiation}

During March 2017, the process of selection of matrices was carried out in conserved or partially conserved forest environments of the Federal District, the municipality of Planaltina, state of Goiás and the municipality of Buritis, state of Minas Gerais. The sampling regions were characterized by typical

Revista Árvore 2019;43(3):e430304 
Cerrado vegetation but, in all regions, there were areas close to degraded vegetation, mainly for agriculture, livestock and roads. The collections were performed in the following areas:

Buritis - The matrices sampled in this area are located in pasture areas with remnants of nearby cerrado. The collection area is all surrounded by cerrado sensu stricto which allows good pollination, dispersion and random crossings between the matrices. Located in the municipality of Buritis-MG. 30 matrices.

FAL - Similar to Buritis area. It has a nearby urban area as well as agricultural research facilities such as grazing and planting of commercial cultivars. Located in the Água Limpa Farm of the University of Brasilia-DF. 26 matrices.

Planaltina - Preserved area with rural occupation in its surroundings. Located in the municipality of Planaltina-GO. 23 matrices.

Sobradinho - The matrices of this region are remnants of urban occupation in the area. They are native individuals who were preserved to compose green areas and preservation of residential condominiums. Located in the administrative region of Sobradinho-DF. 16 matrices.

In all, seeds were collected from 73 matrices in four populations, having as criteria of selection the tree health, minimum distance of 50 meters between matrices, and seed production in the year of collection. After the ripe fruits were collected, they were placed in individual containers by matrix, with their respective identifications, and kept in a shady place. A total of 152 fruits were obtained from 73 matrices ( 1 to 5 fruits collected per matrix). All were measured (diameter and height) with a tape measure and weighed using precision digital scales. The seeds were removed from the fruits and separated from the impurities with later cold storage. At least 10 seeds from each matrix were separated for length, width and thickness measurements using a digital caliper. The mass of 100 seeds (per matrix) was evaluated using precision digital scales and following the guidelines of the Seed Analysis Rules of eight repetitions of 100 seeds each (Brasil, 2009).

\subsection{Data analysis}

Fruit and seed measurements were recorded in the Excel spreadsheet, Microsoft 2010, and statistical analyzes were performed using the IBM SPSS (2012) software. Descriptive analysis of quantitative variables was presented as mean, standard deviation, minimum and maximum values, quartiles and frequency histogram.

The comparison of fruit measurement data was performed by one-way analysis of variance, using the four study populations as a factor, Pearson correlation test, and hierarchical cluster measurement to evaluate intra and inter-population similarities. The hierarchical cluster study among the 73 matrices of the four populations studied was performed using the Ward method and Euclidean distance as a measure.

For seed data analysis, a 2-way ANOVA (population and matrix within each population) was used to evaluate the difference in measurements between the populations and between the matrices of the respective populations. Correlation analysis was also performed between the studied variables. The confidence level adopted was 5\%.

\section{RESULTS}

The fruits obtained had a diameter ranging between 9.10 and $19.40 \mathrm{~cm}$ and height between 8.37 and $19.01 \mathrm{~cm}$. The diameter / height ratio ranged from 0.95 to 1.10 , with a mass between 548.65 and 2157.89 g. The smallest amount of seeds per fruit was 30 seeds and the largest amount found was 169 seeds in the same fruit. The mass of 100 seeds ranged from 36.67 to $176.91 \mathrm{~g}$ (Table 1).

Pearson's correlation analysis ( $r$ ) showed a high correlation between characteristics such as diameter and height ( $\mathrm{r}=0.830$, p-value $<0.001$ ), diameter and mass $(\mathrm{r}=0.806$, $\mathrm{p}$-value $<0.001)$ and height and mass $(\mathrm{r}=0.746, \mathrm{p}$-value $<0.001)$. These data are expected considering that larger fruits tend to have greater mass. The other correlations were not significant at $5 \%$ significance.

In the hierarchical cluster study, 11 small groups and two large groups were grouped, and in these two large groups there are representatives of the four studied populations of. This shows that, based on the phenotypic characteristics of the fruits, there is no specific division of populations, indicating high genetic diversity within populations and among these populations of $A$. crassiflora of central Brazilian cerrado (Figure 1).

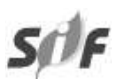

Revista Árvore 2019;43(3):e430304 
Table 1 - Descriptive analysis of the morphometric data of Annona crassiflora fruits obtained in four cerrado populations of Central Brazil, 2017.

Tabela 1 - Análise descritiva dos dados morfométricos de frutos de Annona crassiflora obtidos em quatro populações de cerrado do Brasil

\begin{tabular}{|c|c|c|c|c|c|c|c|}
\hline Variable & Population & $\mathrm{N}$ & Mean & $\begin{array}{c}\text { Standard } \\
\text { Deviation }\end{array}$ & $\begin{array}{l}\text { Coefficient } \\
\text { of variation }\end{array}$ & Min. & Max. \\
\hline \multirow{5}{*}{ Diameter $(\mathrm{cm})$} & Sobradinho & 11 & 12.2303 & 2.57426 & 21.0482 & 9.10 & 19.40 \\
\hline & FAL & 16 & 12.5271 & 1.24384 & 9.9292 & 10.40 & 14.15 \\
\hline & Planaltina & 20 & 12.5042 & 1.09885 & 8.7878 & 10.80 & 14.40 \\
\hline & Buritis & 26 & 14.2366 & 1.43205 & 10.0589 & 11.10 & 16.50 \\
\hline & Total & 73 & 13.0849 & 1.73977 & 13.296 & 9.10 & 19.40 \\
\hline \multirow[t]{5}{*}{ Height (cm) } & Sobradinho & 11 & 11.9425 & 2.60383 & 21.8031 & 8.37 & 19.01 \\
\hline & FAL & 16 & 12.0692 & 1.44845 & 12.0012 & 9.36 & 14.30 \\
\hline & Planaltina & 20 & 11.9079 & 1.07292 & 9.0102 & 10.27 & 14.11 \\
\hline & Buritis & 26 & 13.2877 & 1.36015 & 10.2362 & 10.14 & 15.60 \\
\hline & Total & 73 & 12.4399 & 1.65268 & 13.2853 & 8.37 & 19.01 \\
\hline \multirow[t]{5}{*}{ Diameter/Height } & Sobradinho & 11 & 1.0273 & 0.04334 & 4.2188 & 0.98 & 1.10 \\
\hline & FAL & 16 & 1.0413 & 0.04486 & 4.3081 & 0.95 & 1.11 \\
\hline & Planaltina & 20 & 1.0511 & 0.04064 & 3.8664 & 0.96 & 1.11 \\
\hline & Buritis & 26 & 1.0719 & 0.02659 & 2.4806 & 1.02 & 1.11 \\
\hline & Total & 73 & 1.0528 & 0.04029 & 3.8269 & 0.95 & 1.11 \\
\hline \multirow[t]{5}{*}{ Mass (g) } & Sobradinho & 11 & 1179.2964 & 389.57463 & 33.0345 & 548.65 & 2157.89 \\
\hline & FAL & 16 & 1190.4069 & 227.39180 & 19.102 & 854.36 & 1584.62 \\
\hline & Planaltina & 20 & 1334.7931 & 209.42428 & 15.6896 & 1025.49 & 1756.17 \\
\hline & Buritis & 26 & 1518.6660 & 170.00215 & 11.1942 & 1165.87 & 1817.94 \\
\hline & Total & 73 & 1345.2048 & 271.81940 & 20.2065 & 548.65 & 2157.89 \\
\hline \multirow[t]{5}{*}{ Seeds/fruit } & Sobradinho & 11 & 71.8482 & 23.82934 & 33.1662 & 36.00 & 108.00 \\
\hline & FAL & 16 & 81.6456 & 28.24212 & 34.5911 & 35.00 & 151.00 \\
\hline & Planaltina & 20 & 81.2100 & 20.90789 & 25.7455 & 48.00 & 144.00 \\
\hline & Buritis & 26 & 97.5065 & 33.28387 & 34.135 & 30.00 & 169.00 \\
\hline & Total & 73 & 85.6990 & 28.87828 & 33.6973 & 30.00 & 169.00 \\
\hline & Sobradinho & 11 & 56.0964 & 10.37611 & 18.4969 & 40.83 & 73.64 \\
\hline \multirow[t]{4}{*}{ seeds $(\mathrm{g})$} & FAL & 16 & 61.0950 & 10.45942 & 17.1199 & 42.84 & 79.47 \\
\hline & Planaltina & 20 & 58.2935 & 18.83575 & 32.3119 & 40.83 & 112.27 \\
\hline & Buritis & 26 & 60.5012 & 26.13661 & 43.2002 & 36.67 & 176.91 \\
\hline & Total & 73 & 59.3627 & 19.27814 & 32.4752 & 36.67 & 176.91 \\
\hline
\end{tabular}

$\mathrm{N}=$ number of matrices.

$N=$ número de matrizes.

Based on the Euclidean distances for the characteristics, it was possible to evaluate that the fruit mass contributed the most to the cluster formation, with $47.31 \%$ for the dissimilarity found in this analysis.

Seed length ranged from 13.18 to $23.67 \mathrm{~mm}$, width 6.82 to $14.38 \mathrm{~mm}$ and thickness ranged from 5.39 to $10.65 \mathrm{~mm}$ (Table 2). The ratio of width to thickness was calculated to evaluate the seed cylindricity, which ranged from 0.86 to 2.36 (Table 2). This shows that the cylindrical form is not predominant in the seeds of this species, but spherical or flattened forms.

Correlation analysis was also performed between the variables analyzed for $A$. crassiflora seeds.
There was significant correlation between seed characteristics: length and width $(r=0.316, p$-value $<0.001)$, length and thickness $(r=0.234$, p-value $<0.001)$, width and thickness $(\mathrm{r}=0.158$, $\mathrm{p}$-value $<0.001$ ). All correlations were significant at $5 \%$ significance, even with moderate to weak correlation between variables. This indicates that larger values of one seed measure tend to have larger values of the other parameter, even though this increase is not so large but significant.

To assess whether there was a statistically significant difference between the populations studied in relation to morphometric data, one-way or twoway analysis of variance was performed for fruit and 


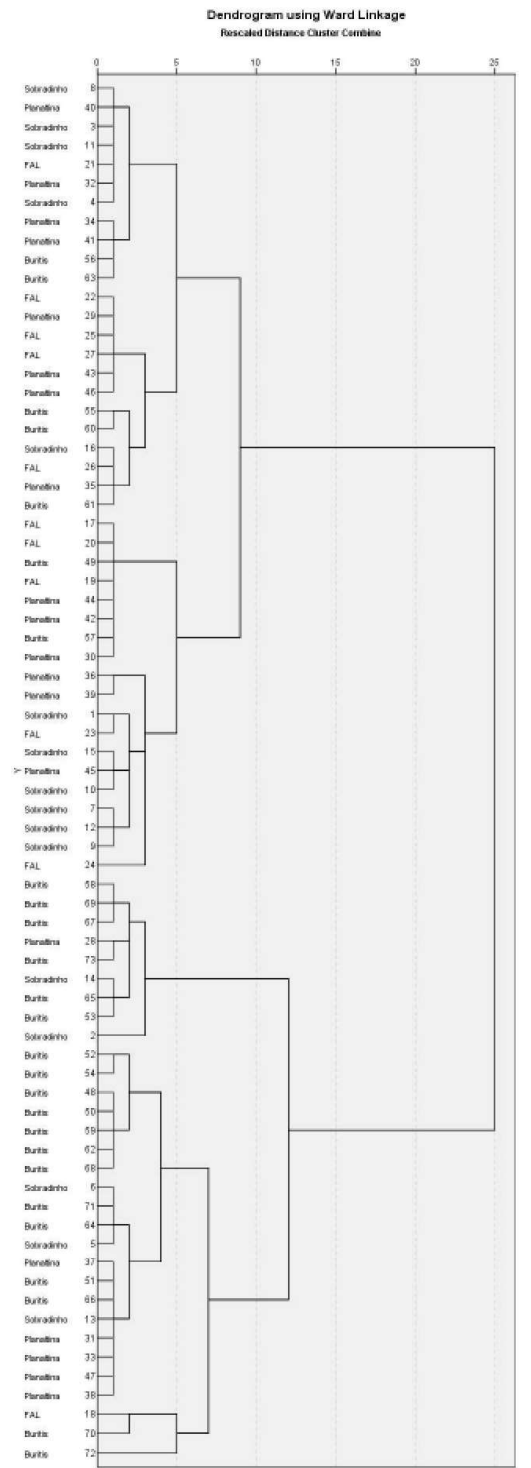

Figure 1 - Dendrogram of the hierarchical clusters analysis of the phenotypic characteristics of the Annona crassiflora fruits obtained in four cerrado populations of Central Brazil, 2017.

Figura 1 - Dendrograma da análise de clusters hierárquica das características fenotípicas dos frutos de Annona crassiflora obtidos em quatro populações de cerrado do Brasil Central, 2017.

seed data, respectively. The unit evaluated in this case was the matrix, where in those with more than one fruit, the average morphometric data were used in the statistical analysis. The post hoc group comparison test used was the Tukey HSD test, whose test is indicated for data with homogeneous variances. Data presented homogeneity of variances by the Levene test, considering that there was no rejection of the assumption of homogeneity of variance ( $p$-value $>$ 0.05 ) for any variable.

It was observed that, for fruit measurements, there was a statistically significant difference in relation to all variables except the 100 seed mass variable $(p$-value $=0.901)$ (Figure 2$)$. For the diameter variable, the null hypothesis of equality of the diameters averages in the four populations was rejected ( $\mathrm{p}$-value $<0.001$ ). Only the Buritis population was statistically different from the other (significantly larger) populations, and they did not differ from each other. For height $(\mathrm{p}$-value $=0.011)$, the same result was found: the Buritis population presented statistically different fruit height than the other populations (significantly higher), and they did not differ from each other. For diameter / height $(p$-value $=0.007)$, the Buritis population differed only from the fruits of the Sobradinho population (significantly larger). The fruit mass presented p-value $<0.001$, showing that the fruit mass of the Buritis population was statistically higher than the fruit mass of the Sobradinho and FAL population. For seeds per fruit, this difference was also observed: p-value $=0.049$, with the number of seeds per fruit of the Buritis population being statistically higher only than that of the Sobradinho population (Figure 2).

Finally, for the mass of 100 seeds there was no division into groups, considering that the null hypothesis of difference of the average mass of 100 seeds of the four populations studied was not rejected.

Regarding the morphometric data of $A$. crassiflora seeds, two-way analysis of variance (population and matrix) was used to assess whether there was a statistically significant difference. The model to represent seed morphometric data was significant for the intercept and the population and matrix factors for all traits analyzed. Regarding the corrected model, $p$-value $<0.001$ was evidenced for all characteristics: length ( $p$-value $<0.001$ ), width (p-value $<0.001)$, thickness ( $p$-value $<0.001$ ) and $\mathrm{L}$ / $\mathrm{E}$ ratio. $(\mathrm{p}$-value $=0.002)$. As with the model, the intercept and both factors were significant ( $\mathrm{p}$-value $<0.050$ ) for all dependent variables.

The post hoc group comparison test used was the Tukey HSD test, which is indicated for data 
Table 2 - Descriptive analysis of the morphometric data of Annona crassiflora seeds obtained in four cerrado populations of Central Brazil, 2017.

Tabela 2 - Análise descritiva dos dados morfométricos de sementes de Annona crassiflora obtidos em quatro populações de cerrado do Brasil Central, 2017.

\begin{tabular}{|c|c|c|c|c|c|c|c|}
\hline Variable & Population & $\mathrm{N}$ & Mean & $\begin{array}{l}\text { Standard } \\
\text { Deviation }\end{array}$ & $\begin{array}{l}\text { Coefficient } \\
\text { of variation }\end{array}$ & Min. & Max. \\
\hline \multirow[t]{5}{*}{ Lenght (mm) } & Sobradinho & 110 & 19.7021 & 2.04106 & 10.35961 & 13.55 & 23.67 \\
\hline & FAL & 160 & 19.7068 & 2.12622 & 10.78927 & 14.28 & 23.55 \\
\hline & Planaltina & 200 & 18.5118 & 1.88877 & 10.20306 & 14.85 & 22.80 \\
\hline & Buritis & 260 & 18.3803 & 1.75698 & 9.559039 & 13.18 & 22.15 \\
\hline & Total & 730 & 18.9063 & 2.0121 & 10.64248 & 13.18 & 23.67 \\
\hline \multirow[t]{5}{*}{ Width (mm) } & Sobradinho & 110 & 10.9883 & 0.98729 & 8.98492 & 8.82 & 14.38 \\
\hline & FAL & 160 & 10.6337 & 0.94084 & 8.84772 & 7.49 & 13.16 \\
\hline & Planaltina & 200 & 10.3275 & 0.93411 & 9.04488 & 7.31 & 12.78 \\
\hline & Buritis & 260 & 9.9022 & 1.00257 & 10.12472 & 6.82 & 12.55 \\
\hline & Total & 730 & 10.3427 & 1.04157 & 10.07058 & 6.82 & 14.38 \\
\hline \multirow[t]{5}{*}{ Thickness (mm) } & Sobradinho & 110 & 8.0241 & 0.73322 & 9.137723 & 5.81 & 10.16 \\
\hline & FAL & 160 & 7.9347 & 0.81094 & 10.22017 & 6.02 & 10.56 \\
\hline & Planaltina & 200 & 7.9501 & 0.59286 & 7.457265 & 5.98 & 9.56 \\
\hline & Buritis & 260 & 7.6082 & 0.79856 & 10.49604 & 5.39 & 9.60 \\
\hline & Total & 730 & 7.8361 & 0.75887 & 9.684282 & 5.39 & 10.56 \\
\hline Width/Thickness & Sobradinho & 110 & 1.3846 & 0.21398 & 15.45428 & 0.99 & 2.36 \\
\hline \multirow[t]{4}{*}{ Ratio } & FAL & 160 & 1.3538 & 0.18117 & 13.38233 & 0.86 & 1.89 \\
\hline & Planaltina & 200 & 1.3051 & 0.14531 & 11.13401 & 0.99 & 1.76 \\
\hline & Buritis & 260 & 1.3132 & 0.17442 & 13.28206 & 0.92 & 2.07 \\
\hline & Total & 730 & 1.3306 & 0.17727 & 13.32256 & 0.86 & 2.36 \\
\hline
\end{tabular}

$\mathrm{N}=$ number of matrices

$N=$ número de matrizes.

with homogeneous variances. The data presented homogeneity of variances by the Levene test, considering that there was no rejection of the assumption of variance homogeneity ( $p$-value $>0.05$ ) for any variable dependent on seed measurements.

Regarding length, two groups were divided in the post hoc test: Buritis and Planaltina were separated from Sobradinho and FAL. That is, the seed length did not differ statistically between Buritis and Planaltina, nor between Sobradinho and FAL, but differed between these groups, where the seed lengths of Buritis and Planaltina were significantly shorter than those of Sobradinho and FAL.

For the width variable, the result of the post hoc test shows that there was division into four groups. This indicates that seed width differed statistically among all populations. Buritis presented the smallest widths and Sobradinho the largest.

Regarding the thickness variable, there was division into two groups, where only the Buritis population differed statistically from the others. Buritis seed thickness was statistically smaller than seed thickness of all analyzed populations. Finally, for the variable width / thickness ratio the seeds differed statistically between the Sobradinho population and the Planaltina and Buritis populations (Figure 3).

\section{DISCUSSION}

The data presented here for seed dimensions are close to those of Machado, et al. (2016), in a study with matrices from the Goiás state region, and of Pimenta, et al. (2013) in headquarters located in Mato Grosso. The variation in seed size of $A$. crassiflora is normal for polyspermic fruits where there is competition for nutrients, which affects the final size. Often, the seeds positioned at the ends of the endocarp, close to the integument, are smaller than those located inside the fruit (Rodrigues, et al., 2006). Thus, these measures may be more influenced by pollination (effectiveness) than by genetic diversity itself. Another point to be emphasized is the physiological seed maturity that directly reflects the seed size. According to Bewley and Black (1994) during the seed filling phase it can vary greatly in volume and size which, in the context of this study, may have a reflection on the morphometric diversity found. 

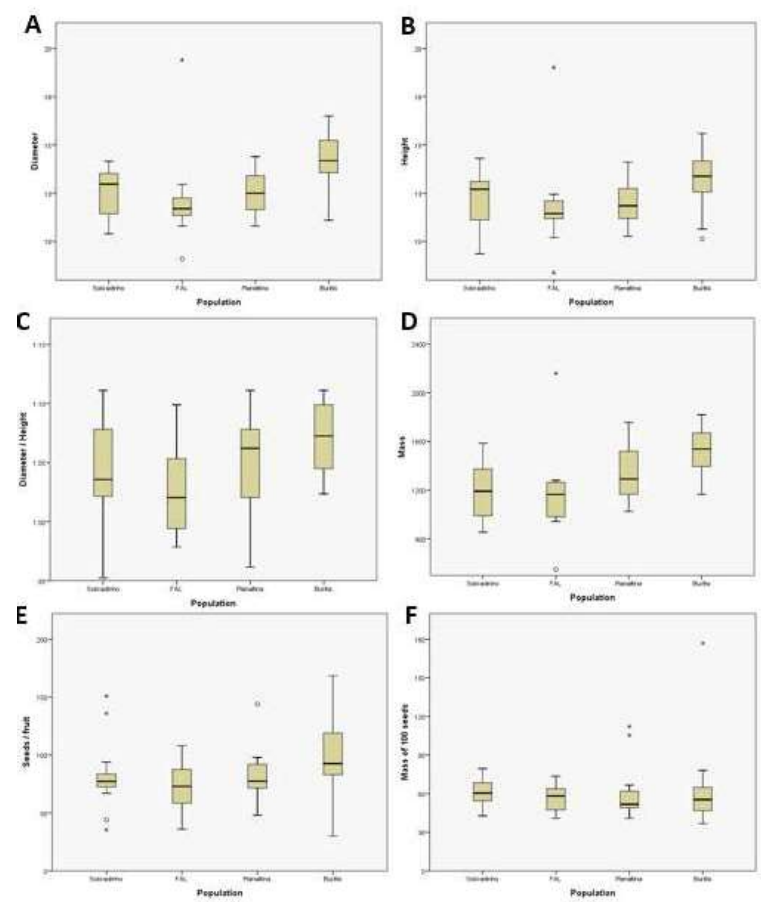

Figure 2 - Box-plot of the morphometric parameters diameter $(\mathrm{cm})(\mathrm{A})$, height $(\mathrm{cm})(\mathrm{B})$, diameter / height $(\mathrm{C})$, mass (g) (D), seeds / fruit (E) and mass of 100 seeds (g) (F) of the fruits of Annona crassiflora in four cerrado populations of Central Brazil, 2017.

Figura 2 - Box-plot dos parâmetros morfométricos diâmetro $(\mathrm{cm})$ $(A)$, altura $(\mathrm{cm})(B)$, diâmetro/altura $(C)$, massa $(g)(D)$, sementes/fruto (E) e massa de 100 sementes $(g)(F)$ dos frutos de Annona crassiflora em quatro populações de cerrado do Brasil Central, 2017.

The $A$. crassiflora population in more conserved areas was able to produce larger, heavier and globular fruits, probably due to the greater availability of resources and pollinators. In this sense the larger number of seeds resulted in smaller seeds. The more anthropized regions presented smaller, lighter fruits, with fewer seeds per fruit, but with larger seeds, which may be a response to some environmental stress (Feller and Vaseva, 2014; Wani, et al., 2016).

Thus, it can be concluded that there is a great morphometric diversity between fruits and seeds of the four populations studied. There was a significant difference in diameter, height, mass and number of seeds per fruit among the populations, and the population of Buritis, in general, had the largest fruits, followed by the population of Planaltina, FAL and lastly Sobradinho. Regarding seed morphometric data, the data were significant, showing morphometric
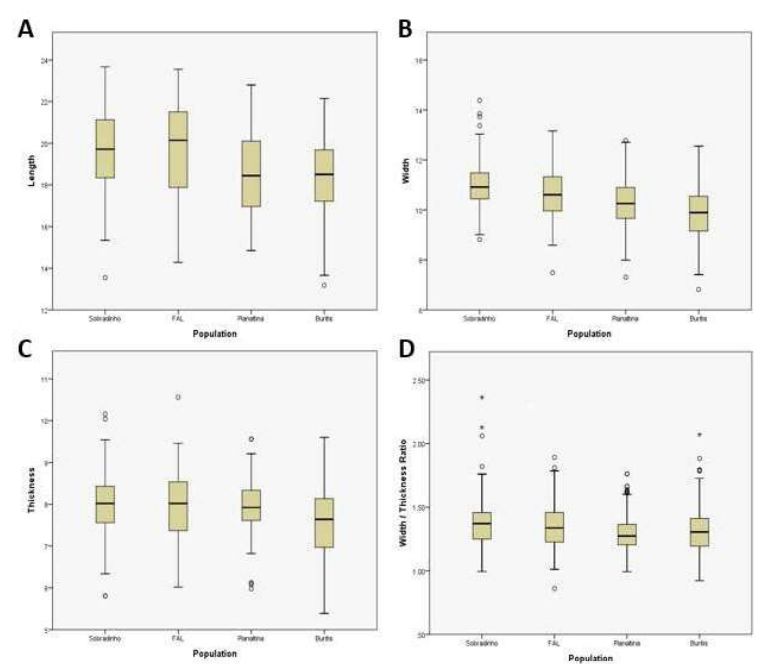

Figure 3 - Box-plot of the morphometric parameters length (mm) (A), width (mm) (B), thickness (mm) (C) and width thickness ratio (D) of Annona crassiflora seeds in four cerrado populations of Central Brazil, 2017.

Figura 3 - Box-plot dos parâmetros morfométricos comprimento $(\mathrm{mm})(\mathrm{A})$, largura $(\mathrm{mm})(B)$, espessura $(\mathrm{mm})(C)$ e razão larguralespessura (D) das sementes de Annona crassiflora em quatro populações de cerrado do Brasil Central, 2017.

differences, where the seeds of Buritis and Planaltina presented the smallest sizes in relation to FAL and Sobradinho. This shows that Buritis and Planaltina presented larger fruits with smaller seeds, and were the Cerrado areas with the highest degree of conservation. The FAL region has many villas around with large land $\left(2500 \mathrm{~m}^{2}\right)$ and the Sobradinho region had even more villas (condominiums), with smaller areas (approximately $1000 \mathrm{~m}^{2}$ ) and bustling avenue. Thus, to improve $A$. crassiflora fruit production for commercial and self-consumption purposes, the ideal is for the population to be in a nearby conserved environment, minimizing anthropogenic effects, since extractivism by itself does not negatively affect this populations (Orioli, 2017) and other Cerrado species (Giroldo and Scariot, 2015; Ferreira, 2016).

However, even though there were significant differences between the morphometric/phenotypic characteristics of the fruits in the four populations, by multivariate evaluation of several characteristics, it was observed that there was no clear division between the populations (cluster analysis). The groups formed based on the phenotypic characteristics of the fruits showed groups with components (matrices) of all four populations. Thus, it can be concluded that there 
is high genetic diversity among all $A$. crassiflora populations studied, as already reported by Zanella, et al. (2012). These authors also show that allogamous species, such as A. crassiflora, tend to have high intrapopulation genetic diversity and little diversity between populations. This fact indicates that there is still genetic diversity of $A$. crassiflora to be studied, conserved and explored.

The original occurrence area of $A$. crassiflora has been suffering anthropogenic pressures such as agricultural expansion, creation of housing and commercial sectors, burning and highways (Orioli, 2017). These pressures culminate in negatively affecting the vegetative, reproductive and productive performance of the species (Chacoff, et al., 2004). Natural replacement of individuals is reduced by all the pressures already mentioned and has serious consequences for local populations of $A$. crassiflora. The low fruit production per individual, allied to the endogenous seed dormancy can create a scenario where the species cannot recompose its population. Thus, $A$. crassiflora is losing more and more space for other competing species, especially forage grasses (Poaceae).

The creation and maintenance of native species germplasm banks is a low cost alternative and with great genetic results. Although it is a medium to long-term initiative, it encompasses aspects such as maintaining genetic variability through seed orchard seedlings (Pontes, et al., 2018), and the possibility of improvement and replacement of genetic material lost in other regions.

Fruit and seed morphometry can be monitored over the long term for comparative studies to monitor the size of propagules of the same population (Macedo, 2009). Such studies may show decreases in the size of fruits and seeds that come from losses of genetic diversity.

\section{CONCLUSION}

Cluster analysis showed two large groups, but with representatives of the four populations. This suggests in addition to the high genetic diversity, that this same diversity is at the intrapopulation level and not between populations.

The fruits of the Buritis population were significantly larger than the other populations, except for the 100 seed mass variable. This larger size of the fruits suggests a greater genetic distance allied to conditions more favorable to pollination given the continuity and preservation of the adjacent Cerrado areas. This pattern was not observed in seed size.

Given this, the analyzes indicate high genetic diversity and larger fruits/seeds in the best conservation areas.

\section{ACKNOWLEDGMENTS}

The authors thank Água Limpa Farm from University of Brasília for their permission to carry out part of the collections and for their logistical and personal support for this work. We also thank the Department of Forest Engineering of the University of Brasília for the infrastructure used in this study.

\section{REFERENCES}

Bewley JD, Black M. Seeds: Physiology of development and germination. Plenum Press: New York, USA, 1992.

Bower AD, Aitken SN. Ecological genetics and seed transfer guidelines for Pinus albicaulis (Pinaceae). American Journal of Botany. 2008;95(1):66-76.

Brasil. Ministério da Agricultura, Pecuária e Abastecimento. Regras para Análise de Sementes (RAS). Brasília: Mapa/Assessoria de Comunicação Social, 2009. 398p.

Chacoff NP, Morales JM, Vaquera MdelP. Efectos de la fragmentación sobre la aborción y depredación de semillas em el Chaco Serrano. Biotropica. 2004;36(1):109-117.

Faleiro FG. Marcadores genético-moleculares aplicados a programas de conservação e uso de recursos genéticos. Planaltina, DF: Embrapa Cerrados, 2007.

Feller U, Vaseva II. Extreme climate events: impacts of drought and high temperature on physiological processes in agronomically important plants. Frontiers in Environmental Science. 2014;39(2):1-17.

Ferreira JB. Impactos causados pelo extrativismo, uso da terra e manejo na persistência de populações de Dipteryx alata Vog. (baru) no Cerrado.

[Dissertação]. Brasília (DF): Universidade de Brasília - Instituto de Ciências Biológicas, Programa de Pós-Graduação em Ecologia; 2016. 
Giroldo AB, Scariot A. Land use and management affects the demography and conservation of an intensively harvested Cerrado fruit tree species. Biological Conservation. 2015;191:150-158.

Higa AR, Silva LD. Pomar de sementes de espécies florestais nativas. Curitiba: Fundação de Pesquisas Florestais do Paraná, 2006.

Hopkin M. Brazilian savannah 'will disappear by 2030'. Nature, 2004.

IBM Corporation. IBM SPSS Statistics for Windows. Version 21.0. Armonk, New York: IBM Corp.; 2012.

Jepson W. A disappearing biome: reconsidering land-cover change in the Brazilian savanna. The Geographical Journal. 2005;171(2):99-111.

Macedo MC, Scalon SPQ, Sari AP, Scalon Filho H, Rosa YBCJ, Robaina AD. Biometria de frutos e sementes e germinaçäo de Magonia pubescens ST. Hil. (Sapindaceae). Revista Brasileira de Sementes. 2009;31(2):202-211.

Machado CG, Oliveira SSC, Cruz SCS, Mendonça NG. Biometria e caracterização morfológica de sementes de araticum oriundas de matrizes de Palminópolis - GO. Global Science and Technology. 2016;9(1):41-47.

Orioli LS. Efeitos de uso de terra e manejo em populações de Annona crassiflora Mart. no Cerrado. [Dissertação]. Brasília (DF): Universidade de Brasília - Instituto de Ciências Biológicas, Programa de Pós-Graduação em Ecologia; 2017.

Pimenta AC, Rego SS, Zuffellato-Ribas KC, Nogueira AC, Koehler HS. Morphological characterization of fruits, seeds and seedlings of araticum plant (Annona crassiflora Mart - Annonaceae). Journal of Seed Science. 2013;35(4):524-531.
Pontes MS, Santiago EF, Nobrega MAS, Freitas VMB. Caracterização morfológica usando dimensões lineares sobre os atributos biométricos em sementes de Annona reticulata (L.) Vell. (ANNONACEAE). Ciência Florestal. 2018;28(2):696-707.

Rodrigues ACC, Osuna JTA, Queiroz SROD, Rios APS. Biometria de frutos e sementes e grau de umidade de sementes de angico (Anadenanthera colubrina (vell.) brenan var. cebil (griseb.) altschul) procedentes de duas áreas distintas. Revista Científica Eletrônica de Engenharia Florestal. 2006;4(8):1-15.

Sano EE, Rosa R, Brito JLS, Ferreira LG. Mapeamento de Cobertura Vegetal do Bioma Cerrado: estratégias e resultados. Planaltina, DF: Embrapa Cerrados, 2007.

Soares-Filho B, Rajão R, Macedo M, Carneiro A, Costa W, Coe M, et al. Cracking Brazil's Forest Code. Science. 2014;344(6182):363-64.

Strassburg BBN, Brooks T, Feltran-Barbiere R, Iribarrem A, Crouzeilles R, Loyola R, et al. Moment of truth for the Cerrado hotspot. Nature Ecology \& evolution, 2017;1(0099):1-3

Vieira RF, Agostini-Costa TS, Silva DB, Sano SM, Ferreira FR. Editores. Frutas nativas da região Centro-Oeste do Brasil. Brasília, DF: Embrapa Informação Tecnológica, 2010.

Wani SH, Kumar V, Shriram V, Sah SK.

Phytohormones and their metabolic engineering for abiotic stress tolerance in crop plants. Crop Journal. 2016;4(3):162-176.

Zanella CM, Janke A, Palma-Silva C, KaltchukSantos E, Pinheiro FG, Paggi GM, et al. Genetics, evolution, and conservation of Bromeliaceae. Genetics and Molecular Biology. 2012;35(4 Suppl):1020-26. 